\title{
Cinnamon oil downregulates virulence genes of poultry respiratory bacterial agents and revealed significant bacterial inhibition: An in vitro perspective
}

\author{
Ahmed Mohammed Erfan ${ }^{1}$ and Sherif Marouf ${ }^{2}$
}

1. National Laboratory for Veterinary Quality Control on Poultry Production, Animal Health Research Institute, Agricultural Research Center, Dokki, Giza, 12618, Egypt; 2. Department of Microbiology, Faculty of Veterinary Medicine, Cairo University, Giza, 12211, Egypt.

Corresponding author: Ahmed Mohammed Erfan, e-mail: ahmed.erfan10000@gmail.com

Co-author: SM: drsherif_marouf@yahoo.com

Received: 14-07-2019, Accepted: 30-09-2019, Published online: 04-11-2019

doi: www.doi.org/10.14202/vetworld.2019.1707-1715 How to cite this article: Erfan AM, Marouf S (2019) Cinnamon oil downregulates virulence genes of poultry respiratory bacterial agents and revealed significant bacterial inhibition: An in vitro perspective, Veterinary World, 12(11): 1707-1715.

\begin{abstract}
Background and Aim: Respiratory bacterial agents represent one of the most harmful factors that ordinarily threaten the poultry industry and usually lead to great economic losses. Meanwhile, there is a global demand to avoid the highly emerging antibiotic resistance and antibiotic residues in edible meat. Whereas, the use of alternatives became of great priority, especially for those substances extracted from natural plant origin. The study aimed to evaluate the antibacterial effect of cinnamon oil as a herbal extract on different respiratory bacterial agents.
\end{abstract}

Materials and Methods: One hundred and fifty biological samples were collected through targeted surveillance for respiratory diseased poultry farms representing three governorates, from which bacterial isolation and identification, DNA sequencing of representative strains were performed. Furtherly, phenotypic and genotypic evaluation of the antibacterial effect of cinnamon oil was performed by minimum inhibitory concentration, agar disk diffusion, and virulence genes expression real-time polymerase chain reaction.

Results: Cinnamon oil gave rise to acceptable degrees of virulence genes downregulation of 0.15, 0.19, 0.37, 0.41, 0.77, and 0.85 for Staphylococcus aureus sed gene, Escherichia coli stx 1 gene, Avibacterium paragallinarum HPG-2 gene, Pasteurella multocida ptfA gene, Mycoplasma gallisepticum $\mathrm{Mgc} 2$ gene, and Ornithobacterium rhinotracheale adk gene, respectively. Phenotypically, using agar disk diffusion assay and broth microdilution susceptibility, cinnamon oil showed also tolerable results as it stopped the growth of $S$. aureus, E. coli, P. multocida, and A. paragallinarum with varying zones of inhibition.

Conclusion: The encountered results declared the successful in vitro effect of cinnamon oil that recommends its application for living birds for future use as a safe antibacterial in the poultry industry.

Keywords: bacteria, cinnamon, expression, gene sequence, poultry, respiratory.

\section{Introduction}

Respiratory diseases are a significant component of the overall disease incidence in poultry [1]. In many cases, respiratory disease cases detected in poultry farms may represent a part of a predominant disease with lower input of other biosystems [2]. Different microbial agents can initiate respiratory disease syndromes in poultry [3]. Environmental distress can raise the effect of such pathogens, leading to more serious disease cases [4]. Several disease agents as Ornithobacterium rhinotracheale, Escherichia coli, Avibacterium paragallinarum, Pasteurella multocida, Mycoplasma gallisepticum, and Bordetella avium were frequently isolated from poultry suffering from respiratory diseases complexes [5]. One approach

Copyright: Erfan and Marouf. Open Access. This article is distributed under the terms of the Creative Commons Attribution 4.0 International License (http://creativecommons.org/licenses/ by/4.0/), which permits unrestricted use, distribution, and reproduction in any medium, provided you give appropriate credit to the original author(s) and the source, provide a link to the Creative Commons license, and indicate if changes were made. The Creative Commons Public Domain Dedication waiver (http:// creativecommons.org/publicdomain/zero/1.0/) applies to the data made available in this article, unless otherwise stated. implemented to overcome the bacterial resistance mechanisms are the use of plant extracts or essential oil either singly or in combination. It also protects the birds from the possible adverse effects of the chemical antibiotics and moreover, protects the consumers from the harmful effect of the residues of the antibiotics that remain in birds' meat and organs [6]. The antimicrobial activity of essential oils and their components has been recognized for a very long time. Essential oils are made from a very complex mixture of volatile molecules that are produced by the secondary metabolism of aromatic and medicinal plants and can be obtained by distillation of different parts of plants [7]. Herbs and spices have been used since ancient times, not only as antioxidants and flavoring agents but also for their antimicrobial activity [8]. The essential oils of aromatic plants are commonly used in food preservation and flavoring, such as cinnamon (Cinnamomum zeylanycum Boiss), a member of the Lauraceae family that grows in Southern Asia. It is well documented that compounds that have phenolic groups were the most effective; thus, the oils of cinnamon, thyme, and rosemary have been found to be most effective against foodborne 
microorganisms [9]. The antimicrobial effect of cinnamon essential oil against various bacteria such as $E$. coli, Pseudomonas aeruginosa, Enterococcus faecalis, Staphylococcus aureus, Salmonella spp., and Vibrio parahaemolyticus has been reported [10]. The prevalent active compound that was usually reported in cinnamon oil is cinnamaldehyde [11]. A past study [12] summarized the antibacterial modes of action of cinnamaldehyde in the following points: Loss of pool metabolites, inhibition of active transport, and disruption of DNA, RNA, proteins, lipids, and polysaccharides synthesis, inhibition of the proton motive force, respiratory chain, electron transfer, and substrate oxidation. Another mode of action of volatile oils is their hydrophobicity, which aids them to disturb the lipid bilayer of the cell membrane, resulting in increased permeability to protons [13]. The overall leakage from bacterial cells and the exit of critical molecules leads to bacterial cell death [11].

The significance of the study becomes clear as there are many methods for studying antibacterial mechanisms from which testing bacterial virulence genes expression on mRNA by real-time polymerase chain reaction (PCR) is a very promising tool. To determine mRNA gene expression, quantitative realtime reverse transcriptase PCR is one of the most commonly used molecular techniques as it usually shows high specificity, sensitivity, reproducibility, and a wide dynamic range [14].

The study aimed to assess the possible antibacterial effect of cinnamon essential oil against surveyed bacterial agents incriminated in poultry suffering from respiratory manifestation and to determine through minimum inhibitory concentration (MIC) and also through studying the expression of specific genes by real-time PCR.

\section{Materials and Methods}

Ethical approval

The current study was approved by the Ethical Committee for live birds sampling at the Animal Health Research Institute, Egypt (License No. AHRI 42102017), according to local Egyptian laws.

\section{Samples collection}

During 3 months (October 2017-December 2017), 150 samples (30 infraorbital sinus exudates, 50 trachea, 20 air sacs, and 50 lung tissues) were collected from poultry farms showing respiratory manifestations in three Egyptian Governorates representing middle, lower, and upper Egypt (Giza, El-Kalyobia, and Beni Suef, respectively). Samples were aseptically collected, transported to the lab by the research team.

\section{Microbiological analysis}

All samples were pre-enriched into broth media; brain heart infusion (BHI) broth (Oxoid, Basingstoke, Hampshire, England, UK) or Mycoplasma broth (Oxoid, Basingstoke, Hampshire, England, UK) in case of Mycoplasma detection. A loopful was streaked into different microbiological media including $5 \%$ sheep blood agar media (Columbia Blood Agar base; Oxoid, Basingstoke, Hampshire, England, UK), MacConkey agar (Thermo Fisher Scientific, GmbH, Germany), Mannitol Salt Agar (HiMedia Laboratories, Mumbai), and Mycoplasma agar media (Oxoid, Basingstoke, Hampshire, England, UK). The inoculated plates were incubated for $48 \mathrm{~h}$ at $37^{\circ} \mathrm{C}$ in aerobic or anaerobic conditions except for Mycoplasma species where the incubation period extended up to 14 days under microaerophilic condition. Pure cultures were identified biochemically by conventional methods [15-17].

\section{Molecular identification}

\section{$P C R$}

All biochemically identified isolates were DNA extracted using QIAamp DNA Mini kit (Qiagen, $\mathrm{GmbH}$, Germany), then genetically identified by PCR using specific primers supplied from Metabion (Germany) and Bio Basic (Canada). NanoDrop ND-1000 spectrophotometer (NanoDrop, USA) was used to check the quantity and quality of the purified DNA. The sequences and cycling conditions of the different used PCR primers are listed in Table-1 [18-23]. PCR reaction $(25 \mu \mathrm{l})$ contained $12.5 \mu 1$ of EmeraldAmp GT PCR Master Mix (Takara, Japan), $1 \mu 1$ of 20 pmol concentration of each primer, $4.5 \mu \mathrm{l}$ of water, and $6 \mu \mathrm{l}$ of the DNA template. PCR reactions were performed in Applied Biosystems 2720 Thermal Cycler. Each PCR product was loaded in a separate well in $1.5 \%$ agarose gel, then photographed and analyzed using a gel documentation system (Alpha Innotech, Biometra, Germany) through its computer software (BioDocAnalyze 2.64.8.1).

\section{Differential gene expression real-time PCR}

\section{Bacterial RNA extraction}

Before RNA purification from bacterial harvests, $1 \mathrm{ml}$ of RNAprotect Bacteria Reagent (Qiagen, Germany, GmbH) was mixed with $0.5 \mathrm{ml}$ of the fresh bacterial broth, kept for 5 min at room temperature to prevent bacterial RNA degradation. Then, $200 \mu \mathrm{l}$ of Tris EDTA buffer containing $1 \mathrm{mg} / \mathrm{ml}$ Lysozyme (Thermo Fisher Scientific, GmbH, Germany) was added to pelleted bacteria. Bacterial RNA extraction was performed following the "Enzymatic Lysis" procedure of QIAamp RNeasy Mini kit (Qiagen, Germany, GmbH). During RNA extraction, on-column DNase digestion was done to remove residual DNA.

\section{SYBR green real-time PCR}

PCR reaction was applied in a Stratagene MX3005P real-time PCR machine where the specific primers were utilized in a one-step $25 \mu 1$ reaction comprising $12.5 \mu 1$ of the $2 \times$ QuantiTect SYBR Green PCR Master Mix (Qiagen, Germany, GmbH), $0.25 \mu$ l of RevertAid Reverse Transcriptase $(200 \mathrm{U} / \mu \mathrm{L})$ (Thermo Fisher Scientific, GmbH, Germany), $0.5 \mu 1$ 
of different primer (20 pmol conc.), $8.25 \mu 1$ of PCR grade water, and $3 \mu \mathrm{l}$ of purified RNA.

The relative expression of each virulence gene was normalized using the related bacterial housekeeping gene. Relative quantitation of gene expression on the RNA templates of the different samples was estimated, the CT value of each sample was compared with that of the control untreated sample through the $\Delta \Delta \mathrm{Ct}$ method, and samples were tested in triplicates [24]. Primers sequences for reference housekeeping and target genes for each microbial agent are listed in Table-2 [19,20,22,23,25-32].

\section{DNA sequencing}

Partial sequencing of different confirmatory genes for different tested bacterial pathogens (S. aureus clfA, A. paragallinarum HPG-2, M. gallisepticummgc2, E. coli phoA, P. multocida kmt1, and $O$. rhinotracheale $16 S \mathrm{r} R N A$ ) was performed using specific primers. QIAquick PCR product extraction kit (Qiagen, Valencia) was used to purify PCR products. Bigdye Terminator V3.1 Cycle Sequencing Kit (PerkinElmer) was used to perform sequencing reactions, and then it was purified using CentriSep Spin Column. DNA sequences were generated using Applied Biosystems 3130 Genetic Analyzer (HITACHI, Japan). Sequence identity to GenBank accessions was established through BLAST $^{\circledR}$ analysis (Basic Local Alignment Search Tool) [33]. The sequence identities were determined by the MegAlign module of Lasergene DNAStar [34], and phylogenetic analyses were done using maximum likelihood, neighbor-joining, and maximum parsimony in MEGA6 [35].

\section{Antimicrobial effect of cinnamon essential oil}

Commercial essential oil $(10.000 \mu \mathrm{g} / \mathrm{mL})$ was obtained from National Research Center, Dokki, Giza. The antimicrobial activity of cinnamon essential oil was determined using agar disk diffusion assay and broth microdilution susceptibility test against different bacterial isolates [10].

\section{Agar disk diffusion assay}

One hundred microliters of bacterial suspensions $\left(1.5 \times 10^{8} \mathrm{CFU} / \mathrm{mL}\right)$ were spread on Mueller-Hinton agar plates and then filter paper disks $(6 \mathrm{~mm}$ in diameter) were impregnated with $10 \mu \mathrm{L}$ of the cinnamon essential oil $(5000 \mu \mathrm{g} / \mathrm{mL})$. The plates were incubated aerobically or anaerobically at $37^{\circ} \mathrm{C}$ for $24-48 \mathrm{~h}$ according to tested bacteria. The diameters of the inhibition zones were measured in $\mathrm{mm}$. All experiments were performed in triplicates [10].

\section{Microdilution susceptibility test}

According to a previous study [10], two-fold serial dilutions of the cinnamon oil were diluted in BHI broth. The following concentrations of essential oil (5000-156.25 $\mu \mathrm{g} / \mathrm{mL}$ with two folds decreasing concentrations in between) were used. Twenty microliters of the inoculum were added to each well of a 96-well microplate containing $160 \mu \mathrm{L}$ BHI broth. Twenty microliters from the stock solutions of cinnamon oil were added into each well; the last well in each raw contained $180 \mu \mathrm{L}$ of broth and $20 \mu \mathrm{L}$ of the inoculum without any cinnamon oil as a negative control. The microplates were incubated in standard conditions (according to used microorganisms). Thereafter, the absorbance (A560) for the plates was

Table-1: Sequences and cycling conditions of the different used PCR primers for the amplification of different bacterial isolates.

\begin{tabular}{|c|c|c|c|c|c|c|c|}
\hline \multirow[t]{2}{*}{ Bacterial agent } & \multirow[t]{2}{*}{ Gene } & \multirow[t]{2}{*}{ Primer sequencing } & \multirow{2}{*}{$\begin{array}{l}\text { Amplified } \\
\text { segment }\end{array}$} & \multicolumn{3}{|c|}{ Amplification (35 cycles) } & \multirow[t]{2}{*}{ References } \\
\hline & & & & $\begin{array}{c}\text { Secondary } \\
\text { denaturation }\end{array}$ & Annealing & Extension & \\
\hline S. aureus & clfA & $\begin{array}{l}\text { GCAAAATCCAGCACAAC } \\
\text { AGGAAACGA } \\
\text { CTTGATCTCCAGCCATA } \\
\text { ATTGGTGG }\end{array}$ & 638 bp & $\begin{array}{l}94^{\circ} \mathrm{C} \\
1 \mathrm{~min}\end{array}$ & $\begin{array}{l}55^{\circ} \mathrm{C} \\
1 \mathrm{~min}\end{array}$ & $\begin{array}{l}72^{\circ} \mathrm{C} \\
1 \mathrm{~min}\end{array}$ & {$[18]$} \\
\hline A. paragallinarum & HPG-2 & $\begin{array}{l}\text { TGAGGGTAGTCTTGCA } \\
\text { CGCGAAT } \\
\text { CAAGGTATCGATCGTC } \\
\text { TCTCTACT }\end{array}$ & 500 bp & $\begin{array}{l}94^{\circ} \mathrm{C} \\
30 \mathrm{~s}\end{array}$ & $\begin{array}{l}63^{\circ} \mathrm{C} \\
40 \mathrm{~s}\end{array}$ & $\begin{array}{l}72^{\circ} \mathrm{C} \\
40 \mathrm{~s}\end{array}$ & [19] \\
\hline M. gallisepticum & $M g c 2$ & $\begin{array}{l}\text { CGCAATITGGTCCTAA } \\
\text { TCCCCAACA } \\
\text { TAAACCCACСTCCAGC } \\
\text { ПТАПTСC }\end{array}$ & 300 bp & $\begin{array}{l}94^{\circ} \mathrm{C} \\
30 \mathrm{~s}\end{array}$ & $\begin{array}{l}60^{\circ} \mathrm{C} \\
30 \mathrm{~s}\end{array}$ & $\begin{array}{l}72^{\circ} \mathrm{C} \\
30 \mathrm{~s}\end{array}$ & [20] \\
\hline E. coli & phoA & $\begin{array}{l}\text { CGATTCTGGAAATGGCAAAAG } \\
\text { CGTGATCAGCGGTGA } \\
\text { CTATGAC }\end{array}$ & 720 bp & $\begin{array}{l}94^{\circ} \mathrm{C} \\
30 \mathrm{~s}\end{array}$ & $\begin{array}{l}55^{\circ} \mathrm{C} \\
45 \mathrm{~s}\end{array}$ & $\begin{array}{l}72^{\circ} \mathrm{C} \\
45 \mathrm{~s}\end{array}$ & {$[21]$} \\
\hline P. multocida & $K m t 1$ & $\begin{array}{l}\text { ATCCGCTATTACCCAGTGG } \\
\text { GCTGTAAACGAACTCGCCAC }\end{array}$ & $460 \mathrm{bp}$ & $\begin{array}{l}94^{\circ} \mathrm{C} \\
30 \mathrm{~s}\end{array}$ & $\begin{array}{l}55^{\circ} \mathrm{C} \\
40 \mathrm{~s}\end{array}$ & $\begin{array}{l}72^{\circ} \mathrm{C} \\
45 \mathrm{~s}\end{array}$ & {$[22]$} \\
\hline O. rhinotracheale & $\begin{array}{l}16 S \\
\text { rRNA }\end{array}$ & $\begin{array}{l}\text { GAGAATTAATTTACG } \\
\text { GATTAAG } \\
\text { TTCGCTTGGTCTCCGAAGAT }\end{array}$ & 784 bp & $\begin{array}{l}94^{\circ} \mathrm{C} \\
30 \mathrm{~s}\end{array}$ & $\begin{array}{l}58^{\circ} \mathrm{C} \\
40 \mathrm{~s}\end{array}$ & $\begin{array}{l}72^{\circ} \mathrm{C} \\
50 \mathrm{~s}\end{array}$ & [23] \\
\hline
\end{tabular}

S. aureus=Staphylococcus aureus, E. coli=Escherichia coli, $A$. paragallinarum=Avibacterium paragallinarum, P. multocida=Pasteurella multocida, M. gallisepticum=Mycoplasma gallisepticum, O. rhinotracheale=Ornithobacterium rhinotracheale, $\mathrm{PCR}=$ Polymerase chain reaction 
Table-2: Sequences and cycling conditions of the different used PCR primers for SYBR green real-time PCR gene expression studies.

\begin{tabular}{|c|c|c|c|c|c|c|}
\hline \multirow[t]{2}{*}{ Bacterial agent } & \multirow[t]{2}{*}{ Gene } & \multirow[t]{2}{*}{ Primer sequencing } & \multicolumn{3}{|c|}{ Amplification (35 cycles) } & \multirow[t]{2}{*}{ References } \\
\hline & & & $\begin{array}{l}\text { Secondary } \\
\text { denaturation }\end{array}$ & Annealing & Extension & \\
\hline \multirow[t]{4}{*}{ S. aureus } & Sed & CCAATAATAGGAGAAAATAA & $94^{\circ} \mathrm{C}$ & $57^{\circ} \mathrm{C}$ & $72^{\circ} \mathrm{C}$ & {$[25]$} \\
\hline & & $\begin{array}{l}\text { AAG } \\
\text { ATTGGTATIIITCGTTC }\end{array}$ & $30 \mathrm{~s}$ & $30 \mathrm{~s}$ & $30 \mathrm{~s}$ & \\
\hline & $16 S$ rRNA & CAACGAGCGCAACCCTTAAG & $94^{\circ} \mathrm{C}$ & $57^{\circ} \mathrm{C}$ & $72^{\circ} \mathrm{C}$ & {$[26]$} \\
\hline & & TITGTCACCGGCAGTCAACTT & $30 \mathrm{~s}$ & $30 \mathrm{~s}$ & $30 \mathrm{~s}$ & \\
\hline \multirow[t]{5}{*}{ A. paragallinarum } & HPG-2 & TGAGGGTAGTCTTGCACGC & $94^{\circ} \mathrm{C}$ & $63^{\circ} \mathrm{C}$ & $72^{\circ} \mathrm{C}$ & [19] \\
\hline & & GAAT & $30 \mathrm{~s}$ & $40 \mathrm{~s}$ & $40 \mathrm{~s}$ & \\
\hline & & $\begin{array}{l}\text { CAAGGTATCGATCGTCTCTC } \\
\text { TACT }\end{array}$ & & & & \\
\hline & gyrA & AGTGAGCGTAACGGCAAAGT & $94^{\circ} \mathrm{C}$ & $58^{\circ} \mathrm{C}$ & $72^{\circ} \mathrm{C}$ & {$[27]$} \\
\hline & & ATGTCCGATTCTTCGTCGTC & $30 \mathrm{~s}$ & $30 \mathrm{~s}$ & $30 \mathrm{~s}$ & \\
\hline \multirow[t]{5}{*}{ M. gallisepticum } & Mgc2 & CGCAATTTGGTCCTAATCCCC & $94^{\circ} \mathrm{C}$ & $60^{\circ} \mathrm{C}$ & $72^{\circ} \mathrm{C}$ & {$[20]$} \\
\hline & & AACA & $30 \mathrm{~s}$ & $30 \mathrm{~s}$ & $30 \mathrm{~s}$ & \\
\hline & & $\begin{array}{l}\text { TAAACCCACCTCCAGCTTTAT } \\
\text { TTCC }\end{array}$ & & & & \\
\hline & $16 S$ rRNA & GAGCTAATCTGTAAAGTTGGTC & $94^{\circ} \mathrm{C}$ & $55^{\circ} \mathrm{C}$ & $72^{\circ} \mathrm{C}$ & {$[28]$} \\
\hline & & GCTTCCTTGCGGTTAGCAAC & $30 \mathrm{~s}$ & $30 \mathrm{~s}$ & $30 \mathrm{~s}$ & \\
\hline \multirow{5}{*}{ E. coli } & Stx 1 & ATG TCA GAG GGA TAG ATC & $94^{\circ} \mathrm{C}$ & $56^{\circ} \mathrm{C}$ & $72^{\circ} \mathrm{C}$ & [29] \\
\hline & & & $30 \mathrm{~s}$ & $30 \mathrm{~s}$ & $30 \mathrm{~s}$ & \\
\hline & & $\begin{array}{l}\text { TAT AGC TAC TGT CAC CAG } \\
\text { ACA AT }\end{array}$ & & & & \\
\hline & $16 S$ rRNA & GCTGACGAGTGGCGGACGGG & $94^{\circ} \mathrm{C}$ & $55^{\circ} \mathrm{C}$ & $72^{\circ} \mathrm{C}$ & {$[30]$} \\
\hline & & TAGGAGTCTGGACCGTGTCT & $30 \mathrm{~s}$ & $30 \mathrm{~s}$ & $30 \mathrm{~s}$ & \\
\hline \multirow[t]{6}{*}{ P. multocida } & ptfA & TGTGGAATTCAGCATITTAGTG & $94^{\circ} \mathrm{C}$ & $55^{\circ} \mathrm{C}$ & $72^{\circ} \mathrm{C}$ & {$[31]$} \\
\hline & & TGTC & $30 \mathrm{~s}$ & $40 \mathrm{~s}$ & $45 \mathrm{~s}$ & \\
\hline & & TCATGAATTCTTATGCGCAAAA & & & & \\
\hline & & TCCTGCTGG & & & & \\
\hline & $K m t 1$ & ATCCGCTATTTACCCAGTGG & $94^{\circ} \mathrm{C}$ & $55^{\circ} \mathrm{C}$ & $72^{\circ} \mathrm{C}$ & {$[22]$} \\
\hline & & GCTGTAAACGAACTCGCCAC & $30 \mathrm{~s}$ & $40 \mathrm{~s}$ & $45 \mathrm{~s}$ & \\
\hline \multirow[t]{4}{*}{ O. rhinotracheale } & adk & GGCAGTGGAAAAGGAACTCA & $94^{\circ} \mathrm{C}$ & $52^{\circ} \mathrm{C}$ & $72^{\circ} \mathrm{C}$ & {$[32]$} \\
\hline & & TCTAAACTTCCTTCGCCGTTT & $30 \mathrm{~s}$ & $30 \mathrm{~s}$ & $30 \mathrm{~s}$ & \\
\hline & $16 S$ rRNA & GAGAATTAATTTACGGATTAAG & $94^{\circ} \mathrm{C}$ & $58^{\circ} \mathrm{C}$ & $72^{\circ} \mathrm{C}$ & {$[23]$} \\
\hline & & TTCGCTTGGTCTCCGAAGAT & $30 \mathrm{~s}$ & $40 \mathrm{~s}$ & $50 \mathrm{~s}$ & \\
\hline
\end{tabular}

S. aureus=Staphylococcus aureus, E. coli=Escherichia coli, $A$. paragallinarum=Avibacterium paragallinarum, P. multocida=Pasteurella multocida, M. gallisepticum=Mycoplasma gallisepticum, O. rhinotracheale=Ornithobacterium rhinotracheale, $\mathrm{PCR}=$ Polymerase chain reaction

read by microplate reader spectrophotometry (BioTek Instruments Inc., USA). The MIC was defined as the lowest concentration of the antimicrobial (cinnamon oil) at which the microorganism did not show visible growth. All experiments were performed in triplicates.

\section{Statistical analysis}

The data were analyzed using SPSS version 19 software (SPSS Inc., Chicago, IL), and one-way ANOVA was performed. $\mathrm{P}=0.05$ was the upper limit to determine the statistically significant results. The results were expressed as mean \pm standard deviations of triplicate measurements.

\section{Results}

Incidence of bacteria isolated from the respiratory system

As shown in Table-3, phenotypic characterization (growth characteristics, colony morphology, and biochemical reactions) revealed 48 bacterial isolates (related to six microbial agents) with overall incidence of $32 \%$. Identified microbial agents were E. coli, S. aureus, O. rhinotracheale, P. multocida,
A. paragallinarum, and $M$. gallisepticum. The incidence of those isolates from each governorate and each sample is presented in Table-3. The three governorates showed variable incidences for bacterial isolation; $15.3 \%, 9.3 \%$, and $7.3 \%$ for Giza, Beni Suef, and El-Kalyobia, respectively.

M. gallisepticum showed the highest isolation incidence (16.7\%); while only two $O$. Rhinotracheale isolates were obtained with an incidence of $1.3 \%$.

PCR was able to detect the different screening genes for the six different microbial agents. Representative bands for the screening genes are shown in Figure-1. Furthermore, PCR proved the virulence of the isolated microbial agents as all of isolated microbial agents showed related virulence genes; such genes were the key factors for the evaluation of cinnamon oil effect.

\section{DNA sequence}

DNA sequences were generated for the different microbial genes; GenBank accessions for the sequenced amplicons were obtained. The identity percentage between the sequenced strains related to the same microbial agent is shown in Table-4. 

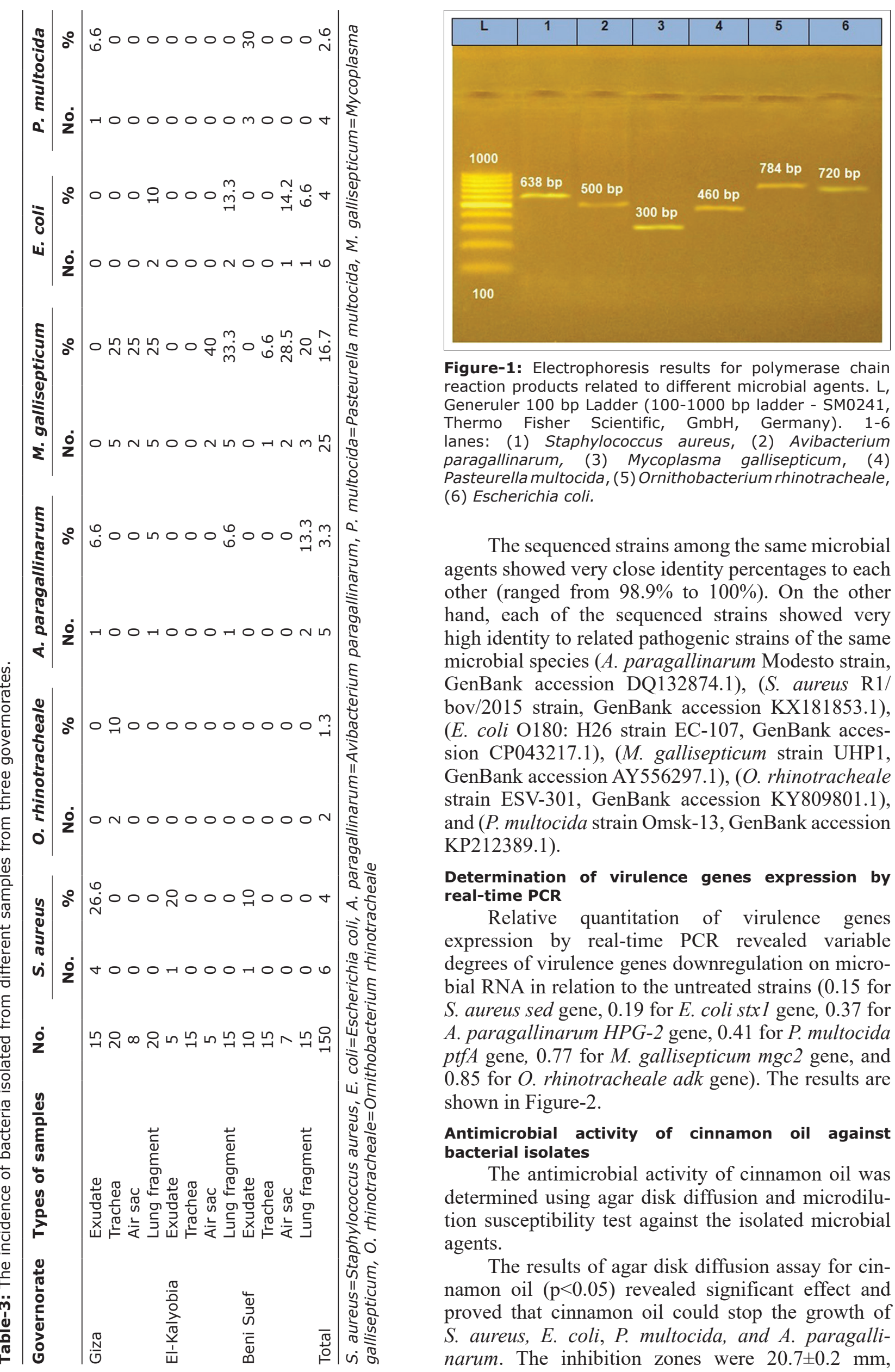

Figure-1: Electrophoresis results for polymerase chain reaction products related to different microbial agents. $L$, Generuler 100 bp Ladder (100-1000 bp ladder - SM0241, Thermo Fisher Scientific, GmbH, Germany). 1-6 lanes: (1) Staphylococcus aureus, (2) Avibacterium paragallinarum, (3) Mycoplasma gallisepticum, (4) Pasteurella multocida, (5) Ornithobacterium rhinotracheale, (6) Escherichia coli.

The sequenced strains among the same microbial agents showed very close identity percentages to each other (ranged from $98.9 \%$ to $100 \%$ ). On the other hand, each of the sequenced strains showed very high identity to related pathogenic strains of the same microbial species (A. paragallinarum Modesto strain, GenBank accession DQ132874.1), (S. aureus R1/ bov/2015 strain, GenBank accession KX181853.1), (E. coli O180: H26 strain EC-107, GenBank accession CP043217.1), (M. gallisepticum strain UHP1, GenBank accession AY556297.1), (O. rhinotracheale strain ESV-301, GenBank accession KY809801.1), and (P. multocida strain Omsk-13, GenBank accession KP212389.1).

\section{Determination of virulence genes expression by real-time PCR}

Relative quantitation of virulence genes expression by real-time PCR revealed variable degrees of virulence genes downregulation on microbial RNA in relation to the untreated strains $(0.15$ for $S$. aureus sed gene, 0.19 for $E$. coli stx 1 gene, 0.37 for A. paragallinarum $H P G-2$ gene, 0.41 for $P$. multocida ptfA gene, 0.77 for $M$. gallisepticum $\mathrm{mgc} 2$ gene, and 0.85 for $O$. rhinotracheale adk gene). The results are shown in Figure-2.

Antimicrobial activity of cinnamon oil against bacterial isolates

The antimicrobial activity of cinnamon oil was determined using agar disk diffusion and microdilution susceptibility test against the isolated microbial agents.

The results of agar disk diffusion assay for cinnamon oil $(p<0.05)$ revealed significant effect and proved that cinnamon oil could stop the growth of S. aureus, E. coli, P. multocida, and A. paragallinarum. The inhibition zones were $20.7 \pm 0.2 \mathrm{~mm}$, 
Table-4: Nucleotide identity matrices for the different bacterial isolates.

\begin{tabular}{lcc}
\hline Bacterial agent & GenBank accessions & Nucleotide identity among Egyptian strains (\%) \\
\hline S. aureus & MG821495-MG821497 & $99.7-99.8$ \\
A. paragallinarum & MG821492-MG821494 & 100 \\
M. gallisepticum & MG820791-MG820793 & $99.3-100$ \\
E. coli & MG821498-MG821500 & 100 \\
P. multocida & MG821501-MG821503 & $98.9-100$ \\
O. rhinotracheale & MG773129-MG773130 & 99.9 \\
\hline
\end{tabular}

S. aureus=Staphylococcus aureus, E. coli=Escherichia coli, $A$. paragallinarum=Avibacterium paragallinarum, P. multocida=Pasteurella multocida, M. gallisepticum=Mycoplasma gallisepticum, 0 . rhinotracheale=Ornithobacterium rhinotracheale

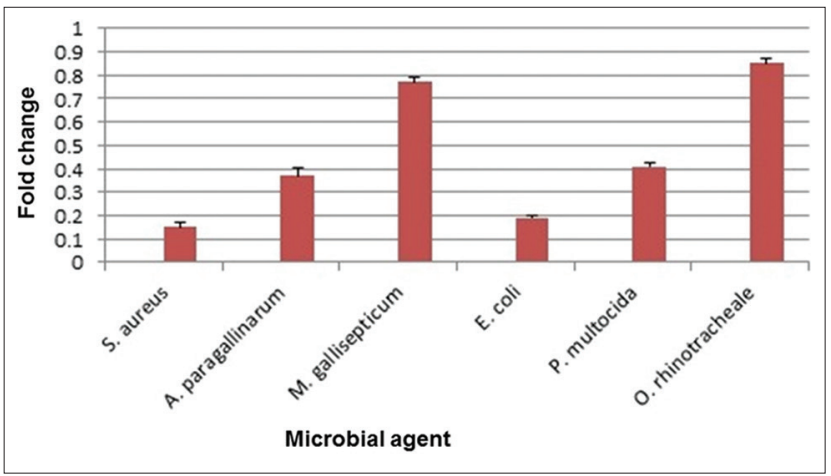

Figure-2: Effect of cinnamon oil on the virulence gene expression of different bacterial agents. Error bars are expressed for mean standard deviations.

$25.5 \pm 0.4 \mathrm{~mm}, 21.5 \pm 0.3 \mathrm{~mm}$, and $27.5 \pm 0.6 \mathrm{~mm}$, respectively. However, O. rhinotracheale and M. gallisepticum showed very small inhibition zones $(5 \pm 0.6 \mathrm{~mm}$ and $3.5 \pm 0.2 \mathrm{~mm}$, respectively).

The dose/response or MIC varied according to the microorganism $(2500 \mu \mathrm{g} / \mathrm{ml}$ for $S$. aureus, $1250 \mu \mathrm{g} / \mathrm{ml}$ for E. coli, $625 \mu \mathrm{g} / \mathrm{ml}$ for both P. multocida, and $A$. paragallinarum). However, O. rhinotracheale and $M$. gallisepticum were able to grow in all cinnamon oil dilutions.

\section{Discussion}

Respiratory diseases represent a great threat to the poultry industry worldwide. In some cases, such as infectious coryza or infectious laryngotracheitis, the disease may be limited to the respiratory system, at least initially [2]. On the other hand, mixed bacterial infections are significant, and the synergistic role between different pathogenic agents may exist. One hundred and fifty samples were studied for the detection of bacterial respiratory disease agents in poultry farms of Giza, El-Kalyobia, and Beni Suef Governorates. Several microorganisms of the genuses Pasteurella (P. multocida, P. gallinarum, $P$. haemolytica, and $P$. anatipestifer), Bordetella (B. avium), and Avibacterium (A. paragallinarum) were involved in respiratory diseases complex. E. coli associated with respiratory infection in chickens has also been reported [36]. O. rhinotracheale has recently been identified as a pathogen causing respiratory tract infections in poultry and other birds [37]. The study revealed 48 bacterial isolates with an incidence of $32 \%$ that were identified as $S$. aureus, E. coli, O. rhinotracheale, P. multocida, A. paragallinarum, and M. gallisepticum. The incidence of those isolates from each governorate and each sample is analyzed in Table-3. Sequenced strains within the same spp. showed a very close identity to each other, as shown in Table-4.

The low MIC value and encountered inhibition zones revealed by disk diffusion in this study revealed that cinnamon essential oil had antibacterial effect (partial bioactivity) against $S$. aureus, E. coli, P. multocida, and A. paragallinarum [8]. Such antimicrobial activity of cinnamon essential oil may be due to the presence of a high concentration of cinnamaldehyde [10]. O. rhinotracheale and M. gallisepticum grew in all dilution of cinnamon oil that reveals that cinnamon oil had no effect on both organisms. The higher resistance of those bacteria to cinnamon oils is possibly due to differential membrane structure of these bacteria.

The isolated microbial agents were proved to be pathogenic as PCR was able to detect specific virulence genes related to different virulence determinants; fimbrial adhesion (P. multocida ptfA gene), enterotoxin ( $S$. aureus Sed gene and E. coli stxl gene), cytadhesin (M. gallisepticum $\mathrm{mgc} 2$ gene), hemagglutinin (A. paragallinarum HPG-2 gene), and adenylate kinase ( $O$. Rhinotracheale adk gene).

Partial DNA sequencing of representative isolates was performed to give some information about the isolated microbial agents and to determine the degree of homology of the tested isolates of the same microbial agents (to avoid the possible differences on response of bacteria to oil due to sequence difference) before performing gene expression real-time PCR study, this was assumed through the very high degree of similarity between the sequenced fragments of the same agent. Furthermore, DNA sequencing confirmed the pathogenicity of the isolated strains through the high identity percentages with the international pathogenic strains.

To estimate the antimicrobial effect of cinnamon oil, relative quantitation real-time PCR of different virulence genes of the isolated bacterial agents were performed, where it showed a very high degree of bacterial virulence genes downregulation that ranged from 0.15 to 0.85 for E. coli stxl gene and $O$. rhinotracheale adk gene, respectively. Realtime PCR results agreed highly with those of phenotypic tests as the highest degree for downregulation 
was encountered for all microbial agents except for $M$. gallisepticum and $O$. rhinotracheale that showed 0.77 and 0.85 downregulation, respectively. The encountered results confirmed the susceptibility of the different isolated bacterial agents to cinnamon oil and supported the results obtained by the disk diffusion method. Although variable degrees of virulence genes downregulation were recorded, this can be accepted as it may be related to variation in virulence gene expression and microbial response differences.

Relative quantitation real-time PCR results were in great concordance with those obtained by MIC and microdilution susceptibility test for the inhibited bacteria even for $M$. gallisepticum and $O$. rhinotracheale as their virulence genes downregulation was 0.77 and 0.85 , respectively; while there was no detectable inhibition for both agents when phenotypic tests were performed.

The varied results encountered for the same essential oil on different pathogenic microbial agents may be explained as the range of the essential oil action against bacteria may only inhibit the bacterial growth (bacteriostatic) or act aggressively to decrease the number of bacterial cells (bactericide). The bacteriostatic action is reversible, as the microbial cells may retrieve their reproductive power after it has been neutralized. However, the bactericidal effect is permanent; as bacterial cells are no more able for growth and reproduction [38].

The degree of downregulation recorded for $M$. gallisepticum and O. rhinotracheale was the lowest among the tested bacteria. Those degrees were not sufficient to be translated to phenotypic inhibition. The disagreed phenotypic and molecular results may be related to RNA translation failure. This failure may be due to some factors as generation of a nonsense codon in the mRNA by transcriptional error [39], failure of ribosome binding to mRNA, ribosomal frameshifting on mRNA leading to the premature termination of translation or endonucleolytic mRNA cleavage [40].

The antibacterial role of cinnamon oil on different bacteria was previously encountered by many authors who proved its powerful effect as $S$. epidermidis icaA gene [41], E. coli O157:H7 Stx gene [42], S. epidermidis mecA gene [43], S. aureus FtsZ gene [44], and S. aureus Sea, Sec, and See genes [45]. Such studies recommended cinnamon oil to be used as an alternative for antibacterial medicines.

Different extraction methods have been proved to possess successful antibacterial effect against Gram-negative or Gram-positive microbial agents, as organic solvents extracts [46], stem ethanolic extracts [47], powder hydroethanolic extract [48], combinations with other herbal extracts [49], or hydrodistillation [50]. Those different methods for extracting cinnamon oil can help medicine companies to produce cinnamon oil on commercial levels.

Toxicity is one of the common adverse effects of herbal extracts; due to that phenomenon, cinnamon oil has been recommended to be diluted to $2 \%$ in case of oral route application [8].

\section{Conclusion}

The reported results have shed some light on the possible use of cinnamon oil and other essential oils for the control of antibiotic-resistant bacterial infections instead of the widely used antibiotics that usually develop bacterial resistance or cause harmful effects for the birds' vital organs in addition to the possible residues that remain in the poultry meat. Further testing of different methods of cinnamon oil extraction should be held. Furthermore, before such application of essential oils on farm levels, toxicity studies should be performed to stand on the safe dose to be applicated.

\section{Recommendations}

We recommend studying the antibacterial effect of cinnamon oil in vivo in different animals in different dilutions and in different routes.

\section{Authors' Contributions}

SM designed this study and applied microbiological experiments. AME performed molecular biology tests. Both authors collected samples, drafted, revised the manuscript, analyzed the data, and approved the final manuscript. Both authors read and approved the final manuscript.

\section{Acknowledgments}

The authors thank the colleagues in National Research Centre, Egypt for supplying the cinnamon oil. We would also like to thank the poultry farms owners for their collaboration during sampling. This work was funded by the National Laboratory for Veterinary Quality Control on Poultry Production, Animal Health Research Institute and by Faculty of Veterinary Medicine, Cairo University.

\section{Competing Interests}

The authors declare that they have no competing interests.

\section{Publisher's Note}

Veterinary World remains neutral with regard to jurisdictional claims in published institutional affiliation.

\section{References}

1. Hassan, K.E., Shany, S.A., Ali, A., Dahshan, A.H., El-Sawah, A.A. and El-Kady, M.F. (2016) Prevalence of avian respiratory viruses in broiler flocks in Egypt. Poult. Sci., 95(6): 1271-1280.

2. Glisson, J.R. (1998) Bacterial respiratory diseases of poultry. Poult. Sci. J., 77(8): 1139-1142.

3. Agunos, A., Carson, C. and Léger, D. (2013) Antimicrobial therapy of selected diseases in Turkeys, laying hens, and minor poultry species in Canada. Can. Vet. J., 54(11): 1041-1052.

4. Shankar, B.P. (2008) Common respiratory diseases of poultry. Vet. World, 1(7): 217-219.

5. Espinosa, I., Colas, M., Vichi, J., Báez, M. and Martínez, S. 
(2011) Isolation and identification of Ornithobacteriun rhinotracheale from laying hens in farms of la Habana Province. Rev. Salud. Anim., 33(1): 38-43.

6. Diaz-Sanchez, S., D’Souza, D., Biswas, D. and Hanning, I. (2015) Botanical alternatives to antibiotics for use in organic poultry production. Poult. Sci. J., 94(6): 1419-1430.

7. Devi, K.P., Nisha, S.A., Sakthivel, R. and Pandian, S.K. (2010) Eugenol (an essential oil of clove) acts as an antibacterial agent against Salmonella Typhi by disrupting the cellular membrane. J. Ethnopharmacol., 130(1): 107-115.

8. Nabavi, S.F., Di Lorenzo, A., Izadi, M., Sobarzo-Sánchez, E., Daglia, M. and Nabavi, S.M. (2015) Antibacterial effects of cinnamon: From farm to food, cosmetic and pharmaceutical industries. Nutrients, 7(9): 7729-7748.

9. Rezaei, M., Ojagh, S.M., Razavi, S.H. and Hosseini, S.M.H. (2010) Development and evaluation of a novel biodegradable film made from chitosan and cinnamon essential oil with low affinity toward water. Food Chem., 122(1): 161-166.

10. Raeisi, M., Tajik, H., Yarahmadi, A. and Sanginabadi, S. (2015) Antimicrobial effect of cinnamon essential oil against Escherichia coli and Staphylococcus aureus. Health Scope, 4(4): e21808.

11. Prabuseenivasan, S., Jayakumar, M. and Ignacimuthu, S. (2006) In vitro antibacterial activity of some plant essential oils. BMC Complement. Altern. Med., 6(39): 1-8.

12. Denyer, S.P. (1995) Mechanisms of action of antibacterial biocides. Int. Biodeterior. Biodegrad., 36(3-4): 227-245.

13. Trumpower, B.L. and Gennis, R.B. (1994) Energy transduction by cytochrome complexes in mitochondrial and bacterial respiration: The enzymology of coupling electron transfer reactions to transmembrane proton translocation. Ann. Rev. Biochem., 63: 675-716.

14. Bustin, S.A. and Nolan, T. (2004) Pitfalls of quantitative real-time reverse-transcription polymerase chain reaction. J. Biomol. Tech., 15(3): 155-166.

15. Barrow, G.I. and Feltham, R.K.A. (1993) Cowan and Steels's Manual for the Identification of Medical Bacteria. $3^{\text {rd }}$ ed. Cambridge University Press, Cambridge, Great Britain.

16. Quinn, P.J., Carter, M.E., Markey, B. and Carter, G.R. (1994) Clinical Veterinary Microbiology. Wolfe Publishing, Mosby-Year Book Limited, London.

17. Van Empel, P.C.M., Van Den Bosch, H., Loeffen, P. and Storm, P. (1997) Identification and serotyping of Ornithobacterium rhinotracheale. J. Clin. Microbiol., 35(2): 418-421.

18. Mason, W.J., Blevins, J.S., Beenken, K., Wibowo, N., Ojha, N. and Smeltzer, M.S. (2001) Multiplex PCR protocol for the diagnosis of staphylococcal infection. J. Clin. Microbiol., 39(9): 3332-3338.

19. Zhao, Q., Sun, Y., Zhang, X., Kong, Y., Xie, Z., Zhu, Y., Zhou, E. and Jiang, S. (2010) Evaluation of two experimental infection models for Avibacterium paragallinarum. Vet. Microbiol., 141(1-2): 68-72.

20. Lynsyansky, I., Garcia, M. and Levisohn, S. (2005) Use of mgc2-polymerase chain reaction-restriction fragment length polymorphism for rapid differentiation between field isolates and vaccine strains of Mycoplasma gallisepticum in Israel. Avian Dis., 49(2): 238-245.

21. Hu, Q., Tu, J., Han, X., Zhu, Y., Ding, C. and Yu, S. (2011) Development of multiplex PCR assay for rapid detection of Riemerella anatipestifer, Escherichia coli, and Salmonella enterica simultaneously from ducks. J. Microbiol. Methods, 87(1): 64-69.

22. OIE. (2012) OIE Terrestrial Manual 2012. Ch. 2.4.1.2. Haemorrhagic Septicaemia. NB: Version adopted, France.

23. Hafez, M.H. (2002) Diagnosis of Ornithobacterium rhinotracheale. Int. J. Poult. Sci., 1(5): 114-118.

24. Yuan, J.S., Reed, A., Chen, F. and Stewart, C.N. (2006) Statistical analysis of real-time PCR data. BMC Bioinformatics, 7(85): 1-12.

25. Mehrotra, M., Wang, G. and, Johnson, W.M. (2000)
Multiplex PCR for detection of genes for Staphylococcus aureus enterotoxins, exfoliative toxins, toxic shock syndrome toxin 1, and methicillin resistance. J. Clin. Microbiol., 38(3): 1032-1035.

26. Levinger, O., Bikels-Goshen, T., Landau, E., Fichman, M. and Shapira, R. (2012) Epigallocatechin gallate induces upregulation of the two-component VraSR system by evoking a cell wall stress response in Staphylococcus aureus. Appl. Environ. Microb., 78(22): 7954-7959.

27. Wen, S., Chen, X., Xu, F. and Sun, H. (2016) Validation of reference genes for real-time quantitative PCR (qPCR) analysis of Avibacterium paragallinarum. PLoS One., 11(12): e0167736.

28. Gomes, A.M., Costa, L.L., Vilela, D.A.R., Marques M.V.R., Carvalhaes, A.G., Marin, S.Y., Costa, M.P., Horta, R.S., Resende, J.S. and Martins, N.R.S. (2010) Detection of Mycoplasma gallisepticum in dead captive psittacines in Belo Horizonte, Brazil. Braz. J. Poult. Sci., 12(2): 75-78.

29. Bélanger, S.D., Boissinot, M., Ménard, C., Picard, F.J. and Bergeron, M.G. (2002) Rapid detection of Shiga toxin-producing bacteria in feces by multiplex PCR with molecular beacons on the smart cycler. J. Clin. Microbiol., 40(4): 1436-1440.

30. Tivendale, K.A., Allen, J.L., Ginns, C.A., Crabb, B.S. and Browning, G.F. (2004) Association of iss and iucA, but not tsh, with plasmid-mediated virulence of avian pathogenic Escherichia coli. Infect. Immun., 72(11): 6554-6560.

31. Tang, X., Zhao, Z., Hu, J., Wu, B., Cai, X., He, Q. and Chen, H. (2009) Isolation, antimicrobial resistance, and virulence genes of Pasteurella multocida Strains from swine in China. J. Clin. Microbiol., 47(4): 951-958.

32. Thieme, S., Mühldorfer, K., Lüschow, D. and Hafez, H.M. (2016) Molecular characterization of the recently emerged poultry pathogen Ornithobacterium rhinotracheale by multilocus sequence typing. PLoS One, 11(2): e0148158.

33. Altschul, S.F., Gish, W., Miller, W., Myers, E.W. and Lipmanl, D.J. (1990) Basic local alignment search tool. $J$. Mol. Biol., 215(3): 403-410.

34. Thompson, J.D., Higgins, D.G. and Gibson, T.J. (1994) CLUSTAL W: Improving the sensitivity of progressive multiple sequence alignment through sequence weighting, position-specific gap penalties and weight matrix choice. Nucleic Acids Res., 22(22): 4673-4680.

35. Tamura, K., Stecher, G., Peterson, D., Filipski, A. and Kumar, S. (2013) MEGA6: Molecular evolutionary genetics analysis version 6.0. Mol. Biol. Evol., 30(12): 2725-2729.

36. EL-Sukhon, S.N., Musa, A. and AL-Attar, M. (2002) Studies on the bacterial etiology of airsacculitis of broilers in Northern and middle Jordan with special reference to Escherichia coli, Ornithobacterium rhinotracheale and Bordetella avium. Avian Dis., 46(3): 605-612.

37. Chin, R.P., Van Empel, P.C.M. and Hafez, H.M. (2003) Ornithobacterium rhinotracheale infection. In: Saif, Y.M., Barnes, H.J., Glisson, J.R., Fadly, A. M.L., McDougald, R. and Swayne, D.E., editors. Diseases of Poultry. $11^{\text {th }}$ ed. Iowa State University Press, Ames, Iowa. p683-690.

38. Bloomfield, S.F. (1991) In: Denyer, S.P. and Hugo, W.B., editors. Mechanisms of Action of Chemical Biocides. Their Study and Exploitation. Methods for Assessing Antimicrobial Activity. Technical Series of the Society for Applied Bacteriology. Blackwell Scientific Publications, Oxford, UK.

39. Bregeon, D., Doddridge, Z.A., You, H.J., Weiss, B. and Doetsch, P.W. (2003) Transcriptional mutagenesis induced byuracil and 8-oxoguanine in Escherichia coli. Mol. Cell., 12(4): 959-970.

40. Bregeon, D., Colot, V., Radman, M. and Taddei, F. (2001) Translational misreading: A tRNA modification counteracts a +2 ribosomal frameshift. Genes. Dev., 15(17): 2295-2306.

41. Nuryastuti, T., van der Mei, H.C., Busscher, H.J., Iravati, S., Aman, A.T. and Krom, B.P. (2009) Effect of cinnamon oil on icaA expression and biofilm formation by Staphylococcus 
epidermidis. Appl. Environ. Microbiol., 75(21): 6850-6855.

42. Sheng, L., Rasco, B. and Zhu, M.J. (2016) Cinnamon oil inhibits Shiga toxin Type 2 phage induction and Shiga toxin Type 2 production in Escherichia coli O157:H7. Appl. Environ. Microbiol., 82(22): 6531-6540.

43. Chovanová, R., Mikulášová, M.,Vaverková, Š. (2016) Modulation of mecA gene expression by essential oil from Salvia sclarea and synergism with oxacillin in methicillin-resistant Staphylococcus epidermidis carrying different types of staphylococcal chromosomal cassette mec. Int. J. Microbiol., 2016: 6475837.

44. Herman, A., Bochenek, J. and Herman, A.P. (2013) Effect of cinnamon and lavender oils on FtsZ gene expression in the Staphylococcus aureus ATCC 29213. Appl. Biochem. Microbiol., 49(5): 481-484.

45. Azizkhani, M. and Parsaeimehr, M. (2015) Effects of Cinnamomum zeylanicum and Ocimum basilicum essential oils on the growth of Staphylococcus aureus ATCC 29213 and gene expression of enterotoxins A, C and E. J. Essent. Oil Res., 27(6): 506-513.
46. Al-Bayati, F.A. and Mohammed, M.J. (2009) Isolation, identification, and purification of cinnamaldehyde from Cinnamomum zeylanicum bark oil. An antibacterial study. Pharm Biol., 47(1): 61-66.

47. Keskin, D. and Toroglu, S (2011) Studies on antimicrobial activities of solvent extracts of different spices. J. Environ. Biol., 32(2): 251-256.

48. Mandal, S., DebMandal, M., Saha, K. and Pal, N.K. (2011) In vitro antibacterial activity of three Indian spices against methicillin-resistant Staphylococcus aureus. Oman Med. J., 26(5): 319-323.

49. Guerra, F.Q., Mendes, J.M., Sousa, J.P., Morais-Braga, M.F., Santos, B.H., Coutinho, H.D.M. and Ede, O.L. (2012) Increasing antibiotic activity against a multidrug-resistant Acinetobacter spp. by essential oils of Citrus limon and Cinnamomum zeylanicum. Nat. Prod. Res., 26(23): 2235-2258.

50. Yap, P.S., Lim, S.H., Hu, C.P. and Yiap, B.C. (2013) Combination of essential oils and antibiotics reduce antibiotic resistance in plasmid-conferred multidrug-resistant bacteria. Phytomedicine, 20(8-9): 710-713. 